\title{
Updating Staff Involvement with Development
}

By: Michael A. Crumpton

Crumpton, M.A. (2014). Updating staff involvement with development. The Bottom Line: Managing library finances, 27(4), 132 - 135. doi: 10.1108/BL-10-2014-0024

This article is (c) Emerald Group Publishing and permission has been granted for this version to appear here http://libres.uncg.edu/ir/uncg/. Emerald does not grant permission for this article to be further copied/distributed or hosted elsewhere without the express permission from Emerald Group Publishing Limited.

Made available courtesy of Emerald Group Publishing Limited: http://www.dx.doi.org/10.1108/BL-10-2014-0024

***@ Emerald Group Publishing Limited. Reprinted with permission. No further reproduction is authorized without written permission from Emerald Group Publishing Limited. This version of the document is not the version of record. Figures and/or pictures may be missing from this format of the document.

\section{Abstract:}

Purpose: The purpose of this article is to reinforce that library staff can be critical to development activities.

Design/methodology/approach: This is a discussion of issues involving personal giving and a case study example.

Findings: Several factors are discussed related to staff behaviors about giving.

Originality/value: This is the author's own experiences and research, the author was involved in the case study.

Keywords: Trust | Development | Support | Behaviors | Philanthropic

\section{Article:}

Two years ago in this column, we discussed the importance of staff involvement with activities surrounding Development and Fundraising in the libraries (Crumpton, 2012). What has changed in two years that warrants another look? Budgets certainly are not better and overall philanthropic giving is flat across the country. Competition for donors is at an all-time high, and donors are becoming more strategic. Has donor activity become more difficult? Are your staff members aware of these challenges and are they helping the library as an organization find new ways to reach donors and promote the needs of the organization? And what about your staff, are they willing to be part of the fundraising effort? 
Actually not much has changed. Because the economy has recovered sluggishly, needs for philanthropic support have never been higher, especially in non-profit organizations such as libraries. And many library staff members have also had flat or decreasing disposable incomes, which make personal giving efforts and support to others harder. But employee support is still a critical component to successful fundraising efforts and should continue to be a consideration of development officers and senior administrators.

A good example of having staffs invest in an organization's philanthropy efforts comes from the Greater New York YMCA. Their Chief Development Officer, Laermer (2013), gives advice on their success with fundraising efforts but also insight into how donors are becoming more strategic and how the YMCA staff, volunteers and members are part of the effort. According to Laermer (2013), donors give where they can see the impact of their contributions, and employees telling their stories are a significant and successful strategy to follow.

But employees can be skeptical, as it relates to giving themselves. Corporate scandals, such as Enron, can cause people to hesitate over making contributions to organizations that they do not know, it is a trust factor (USA Today, 2004). Organizations such as libraries should already be deemed trustworthy, so library employees have a venue for philanthropic activities, the question is are they being asked. Employees who find their libraries trustworthy will not only donate themselves but also be in a better position to support external activities of Development Officers.

\section{Case study}

We decided to find out what encourages employees to donate, to our libraries or externally to organizations of their choice, so we invited employee donors to a focus group to discuss their motivations. The goals included not only understanding better, their sense of giving and why, but also to determine how they feel about development activities engaged by the libraries. The following questions were developed to get the conversation started.

\section{Focus group questions}

Focus Group goal: To gain appropriate feedback from volunteers regarding content on development activities of the library and the perceptions of the role that staff can play. This information is intended to provide context for a larger staff presentation/activity in the spring:

- What is your personal view and activity level regarding philanthropic activity, i.e. giving at the workplace, church, community organizations, etc.? How does it make you feel, what is your motivation?

- What benefits can you see to the organizations in which you donate time, money or other support?

- What is your understanding of development activities within the university and within the University Libraries? Why do you feel it is necessary? 
- What benefits to you see from donor support within the University Libraries? How do you feel such investment in donor relations helps the libraries?

- The libraries are a service oriented profession and donor relations is part of the total scope of activities that we embrace, how can you as individuals be a part of that?

- What terminology do you find confusing? What activities do you not understand? What format of communication regarding development activities is most effective?

The demographics of the focus group were mixed, librarians, staff and supervisors, as well as multiple departments and folks with different levels of primary responsibilities. As a representative group, all participants in the focus group felt that giving was an important component in their life, as a way to give back or support others. There was agreement that everyone should contribute somehow, even as a volunteer if they cannot afford financial support.

It was also generally agreed to by all, that motivation as to where to give, was related to the perceived need and common interest that might be shared by them as a donor and the organization. Trust was also a big factor, as it informs expectations on how financial donations are spent, and having a clear understanding of the benefits that donations made, was very important to future opportunities. Many comments were related to family values and good citizenship as a motivation for giving. This included giving to the church and community organizations that they interacted with.

This translated from folks in the group, who had given to our library, as a sense of "employer as family", giving to support the workplace like they would as family members. This indicates that employees feel that what we do as the "library" is important, and sometimes it just takes the right opportunity or situation to encourage people to give or support the activities. Some ideas for future giving that surfaced included; targeting a project in which everyone could participate in by donating, creating an opportunity to support on a small-scale more frequently and providing choices, so that people could choose something of interest or that had meaning.

Focus group participants understood the value and necessity of development activities for the libraries, especially in times of decreasing budgets and rising costs. They also recognized the changes to traditional funding sources and why philanthropic activities were needed to continue projects certain operations. When they as employees give, they do not expect rewards or attention, just appreciation that it meant something.

But they did not have a clear understanding of terminology being used or how some gifts would benefit the library in the future. There was discussion over meeting donor expectations and questions over whether some situations were inappropriate for the library to accept.

Communicating to the library staff what happens to monies donated was an important concern as well as how any particular donation contributed to the organizational vision or identity. 
We learned from library staff donors that giving for them has personal meaning and that supporting the organizational efforts in other ways depended on the perceived value of the gift, as it related to satisfying an organizational need. Smith (2012) in her article "All Good Works Are Not Created Equal: Employee Sensemaking of Corporate Philanthropy” discusses how members of an organization, in learning to understand the benefits of philanthropic activity, will do so in terms of their own values and beliefs. She also discussed how in some cases, employees give "legs" or actions to charitable commitments made by the organization, which makes employee support even more critical for smooth execution of actions resulting from a donation.

Smith's (2012) article also addresses the social aspect of giving and how recognizing the social context between employees could be important for overall success. As charitable giving is often considered ethically and socially desirable behavior, there can also exist a form of peer pressure to "join in" or share in that positive behavior. This might be best utilized by publicly acknowledging or recognizing staff contributions so as to encourage others to do so as well.

Joyaux is a non-profit consultant for fund development and strategic planning. She talks about building a culture of philanthropy into your organization individual employee by individual employee. By developing an understanding of the vision, for organizational needs and the value of donor support, positive attitudes can be developed that help shape the desired behaviors for staff in dealing with potential contributors. This makes employees ambassadors for the organization and invests them in the outcomes that shape future activities. Joyaux states that once the culture is firmly established, then fund development is easier and more productive.

\section{Conclusion}

Library employees, who contribute to the organization, do so for personnel reasons. Reasons that can influence others and be broadened to also influence external donor candidates. By understanding the critical role that development activities can mean to the organizational health of the library, library staff can make a huge difference in the success or philanthropic activities and events. Talk to your folks; find out what their motivations are and how much more they are willing to help influence and support others. Sometimes, all you have to do is ask.

\section{References and Readings}

1. Crumpton, M.A. (2012), “Development: what's in it for you?”, The Bottom Line: Managing Library Finances, Vol. 25 No. 1, pp. 29-32.

2. USA Today (2004), “Employee giving in an age of skepticism”, USA Today, April.

3. Joyaux, S. available at: www.simonejoyaux.com/

4. Laermer, G. (2013), "Show, tell and involve: fundraising fundamentals for a new era of philanthropy”, Huffington Post, 3 January. 
5. Smith, J.M. (2012), “All good works are not created equal: employee sensemaking of corporate philanthropy”, Southern Communication Journal, Vol. 77 No. 5, pp. 369-388.

\section{Further reading}

1. Chardon, M. (2013), “Peering into the nonprofit crystal ball”, Huffington Post, 8 January.

2. DeBoskey, B. (2013), "Season for giving: nine tips for effective philanthropy”, The Costco Connection,December. 